\title{
MOTIVASI DAN STRATEGI MANAJEMEN LABA PADA ORGANISASI
}

\author{
Ika Neni Kristanti S.E., M.Sc \\ Prodi Akuntansi STIE Putra Bangsa
}

\begin{abstract}
Earnings management occurs when managers use valuations in financial reporting and in compiling transactions to change financial statements so as to mislead some stakeholders regarding the underlying results that depend on reported accounting figures or to influence contract outcomes that depend on reported accounting figures. The existence of earnings management in a company is inseparable from the various types or underlying motivational factors, while some of the motivations associated with the implementation of earnings management are bonus motivation, political motivation, tax motivation, CEO turnover motivation, IPO motivation. The models used in measuring earnings management include: Healy Model, DeAngelo Model, Jones Model, Industrial Model, Jones Modification Model, Dechow-Dichev Model, Kothari Model and Stubben Model.
\end{abstract}

\section{PENDAHULUAN}

\section{Latar Belakang}

Laporan keuangan merupakan media komunikasi yang digunakan untuk menghubungkan pihak-pihak yang berkepentingan terhadap perusahaan. Pentingnya laporan keuangan juga diungkapkan bahwa laporan keuangan merupakan sarana untuk mempertanggungjawabkan apa yang dilakukan oleh manajer atas sumber daya pemilik. Salah satu parameter penting dalam laporan keuangan yang digunakan untuk mengukur kinerja manajemen adalah laba.

Manajemen laba dapat terjadi karena penyusunan statemen keuangan menggunakan dasar akrual. Dengan menggunakan dasar akrual, transaksi atau peristiwa lain diakui pada saat transaksi atau peristiwa lain tersebut terjadi bukan pada saat kas atau setara kas diterima atau dikeluarkan. Sebagai konsekuensi penggunaan dasar akrual ini, dalam statemen keuangan, laba dalam suatu periode dapat mengandung unsur kas dan akrual (non kas).

Unsur akrual dapat terjadi berdasarkan kebijakan manajemen (discretionary accruals) atau non-kebijakan manajemen (nondiscretionary accruals). Laporan keuangan disusun berdasarkan akuntansi berbasis akrual (accruals accounting). Akuntansi akrual mempunyai keuanggulan bahwa informasi laba perusahaan dan pengukuran komponennya berdasarkan akuntansi akrual secara umum memberikan indikasi lebih baik tentang kinerja ekonomi perusahaan daripada informasi yang dihasilkan dari aspek penerimaan dan pengeluaran kas terkini (FASB 1978). Akuntansi akrual juga memiliki kelemahan. Wild et al. (2003) mengkritik bahwa akuntansi akrual merupakan aturan yang tidak sempurna dan mengaburkan laporan keuangan yang bertujuan memberikan informasi ini diakibatkan akuntansi akrual yang ruwet dan rentan atas manipulasi. Kerentanan ini disebut manajemen laba (earnings management).

Kehadiran, motivasi dan peluang merupakan insentif bagi manajer untuk mengelola laba. Menurut Scott (2000), motivasi manajemen laba meliputi rencana bonus, debt covenant, dan biaya politik. Manajer termotivasi mengelola laba untuk mencapai target kinerja dan kompensasi bonus, meminimalkan kemungkinan pelanggaran perjanjian utang, dan meminimalkan biaya politik karena intervensi pemerintah atau parlemen. 
Menurut Statement of Financial Accounting Concept (SFAC) No. 1, informasi laba merupakan perhatian utama untuk menaksir kinerja atau pertanggungjawaban manajemen. Selain itu informasi laba juga membantu pemilik atau pihak lain dalam menaksir earnings power perusahaan di masa yang akan datang. Adanya kecenderungan lebih memperhatikan laba ini disadari oleh manajemen, khususnya manajer yang kinerjanya diukur berdasarkan informasi laba tersebut, sehingga mendorong timbulnya perilaku menyimpang, yang salah satu bentuknya adalah earnings management.

Manajemen mempunyai kewajiban untuk memaksimumkan kesejahteraan para pemegang saham dan debtholders, namun disisi lain manajer juga mempunyai kepentingan untuk memaksimumkan kesejahteraan mereka sendiri. Penyatuan kepentingan pihak-pihak ini seringkali menimbulkan masalah-masalah yang disebut dengan masalah keagenan (agency problem). Manajemen laba merupakan salah satu masalah keagenan yang terjadi karena adanya pemisahan antara pemegang saham dengan manajemen perusahaan.

Manajemen laba dilakukan dengan tujuan tertentu. Misalnya, manajemen laba yang dilakukan dengan menggunakan akrual untuk menaikkan laba untuk tujuan mendapatkan harga saham yang relatif tinggi pada waktu penerbitan saham. Manajemen laba dapat juga dilakukan dengan tujuan mendapatkan keuntungan terkait dengan kepemilikan saham manajemen.

Berdasarkan uraian pada latar belakang di atas maka tujuan dalam penulisan makalah ini adalah: 1) untuk mengetahui faktor yang memotivasi adanya Earning Management pada perusahaan dan 2) untuk mengetahui bagaimanakah strategi Earning Management pada perusahaan dilakukan.

\section{PEMBAHASAN}

\section{Earning Management}

Scott (2003: 369) mendefinisikan earning management sebagai pilihan yang dilakukan oleh manajer dalam menentukan kebijakan akuntansi untuk mencapai beberapa tujuan tertentu. Konsep manajemen laba menggunakan pendekatan teori keagenan (agency theory) yang menyatakan bahwa praktek manajemen laba dipengaruhi oleh konflik antara kepentingan manajemen (agent) dan pemilik (principal) yang timbul karena setiap pihak berusaha untuk mencapai atau mempertimbangkan tingkat kemakmuran yang dikehendakinya.

Scott (2006 : 344) membagi cara pemahaman atas manajemen laba atau earnings management menjadi dua. Pertama, melihatnya sebagai perilaku oportunis manajer untuk memaksimalkan utilitasnya dalam menghadapi kontrak kompensasi, kontrak utang, dan political cost (Oportunistic Earnings Management). Kedua, dengan memandang manajemen laba dari perspektif efficient contracting (Efficient Earnings Management), dimana manajemen laba memberi manajer suatu fleksibilitas untuk melindungi diri mereka dan perusahaan dalam mengantisipasi kejadian-kejadian yang tak terduga untuk keuntungan pihak-pihak yang terlibat dalam kontrak. Dengan demikian, manajer dapat mempengaruhi nilai pasar saham perusahaannya melalui manajemen laba, misalnya dengan membuat perataan laba (income smoothing) dan pertumbuhan laba sepanjang waktu.

Definisi manajemen laba yang hampir sama juga diungkapkan oleh Schipper (1989) yang menyatakan bahwa manajemen laba merupakan suatu intervensi dengan tujuan tertentu dalam proses pelaporan keuangan eksternal, untuk memperoleh beberapa keuntungan privat (sebagai lawan untuk memudahkan operasi yang netral dari proses tersebut).

Aktivitas laba dapat terjadi karena tiga faktor yaitu dengan cara: pemanfaatan transaksi akrual, perubahan metode akuntansi, dan penerapan suatu kebijakan. Manajemen laba merupakan tindakan manajer untuk meningkatkan (mengurangi) laba yang dilaporkan saat ini atas suatu unit dimana manajer bertanggungjawab, tanpa 
mengakibatkan peningkatan (penurunan) profitabilitas ekonomi jangka panjang unit tersebut.

Laporan keuangan disusun berdasarkan akuntansi akrual yang mengharuskan pengakuan pendapatan dan beban berdasarkan saat terjadinya hak dan kewajiban, bukan saat penerimaan dan pengeluaran kas. Laba yang dihasilkan akuntansi berbasis akrual memberikan informasi kinerja ekonomi yang lebih baik daripada laba yang dihasilkan akuntansi berbasis kas (FASB 1978).

Menurut Fischer dan Rosenzweig (1995), manajemen laba merupakan tindakan manajer untuk meningkatkan (menurunkan) laba yang dilaporkan saat kini dari suatu unit yang menjadi tanggung jawab manajer tanpa mengkaitkan dengan peningkatan (penurunan) profitabilitas ekonomi jangka panjang. Akuntansi akrual terdiri dari discretionary accruals (DA) dan non discretionary accruals (NDA). DA merupakan akrual yang ditentukan manajemen, manajer dapat memilih kebijakan dalam hal metode dan estimasi akuntansi. NDA merupakan akrual yang ditentukan atas kondisi ekonomi (Xiong, 2006).

Menurut Healy dan Wahlen menyatakan bahwa manajemen laba terjadi ketika para manajer menggunakan keputusannya dalam pelaporan keuangan dan dalam melakukan penyusunan transaksi untuk mengubah laporan keuangan baik untuk menimbulkan gambaran yang salah bagi stakeholder tentang kinerja ekonomis perusahaan,ataupun untuk mempengaruhi hasil kontraktual yang bergantung pada angka-angka akuntansi yang dilaporkan.

\section{Akrual Pada Akuntansi}

Manajemen yang mempunyai motivasi signalling mencatat discretionary accruals untuk mencerminkan secara lebih baik dampak kejadian ekonomi pokok terhadap kinerja perusahaan. Manajemen mencatat discretionary accruals untuk menyampaikan informasi privat mengenai laba masa depan perusahaan, atau agar laba menjadi ukuran yang lebih dapat dipercaya dan tepat waktu mengenai kinerja perusahaan kini daripada laba non discretionary accruals.

Non discretionary accruals disebut juga dengan normal accruals, yang berarti bahwa non discretionary accruals hanya mengakui transaksi untuk kondisi yang normal saja yaitu kondisi yang sudah ada di dalam kebijakan manajemen perusahaan. Oleh karena itu, laba berdasarkan non discretionary accruals tidak bisa mendeteksi transaksi diluar kondisi yang normal atau di luar kebijakan manajemen perusahaan. Oleh karena itu untuk mendeteksi manajemen laba berdasarkan non discretionary accruals jauh lebih mudah dibandingkan berdasarkan discretionary accruals karena semua transaksi sesuai dengan kebijakan manajemen perusahaan.

Menurut Chen and Cheng (2002) manajer mempunyai dua motivasi untuk mencatat discretionary accruals yaitu: pertama, motivasi kinerja yaitu manajemen mencatat discretionary accruals untuk mencerminkan laba secara lebih baik dampak kejadian-kejadian ekonomi penting terhadap laba. Kedua, motivasi manajemen laba oportunistik yaitu bahwa manajemen mencatat discretionary accruals untuk memaksimalkan manfaat yang mereka peroleh dengan tidak bermaksud untuk mengungkapkan informasi privat.

\section{Motivasi Earning Management}

Watts \& Zimmerman (1986) dan Scott (2000) mengajukan 3 hipotesis motivasi manajemen laba meliputi rencana bonus, debt covenant, dan biaya politik.

1) Rencana Bonus

Rencana bonus menjelaskan peran pilihan kebijakan akuntansi dalam penentuan rencana kompensasi manajemen. Selain gaji bulanan, manajer menerima kompensasi tambahan sesuai kinerjanya. Angka laba sering digunakan untuk mengukur kinerja manajer. Manajer memiliki insentif untuk memilih metode akuntansi dan kebijakan estimasi akuntansi untuk memperbaiki kinerjanya. 
Dechow \& Sloan (1991) menyatakan bahwa manajer meningkatkan kompensasinya dengan pemotongan biaya riset. Healy (1985) menambahkan bahwa manajer memilih penurunan laba ketika informasi tidak mencapai target bonus minimal atau melewati target bonus maksimal.

\section{2) Debt Covenant}

Debt covenant menyatakan bahwa manajer termotivasi melakukan manajemen laba untuk menghindari pelanggaran perjanjian utang. Kreditor biasanya membatasi pembayaran deviden, pembelian kembali saham beredar, dan penambahan utang untuk menjamin pembayaran pokok utang dan bunga (Watts \& Zimmerman 1986). Pembatasan ini dinyatakan dengan angka atau rasio akuntansi misalnya tingkat modal kerja, interest coverage, dan aktiva bersih. Defond \& Jiambalvo (1994) dan Sweeney (1994) mengindikasikan bahwa perusahaan pelanggar perjanjian utang menggunakan akrual untuk meningkatkan laba tahun sebelumnya.

3) Biaya Politik

Proses politik menimbulkan biaya bagi perusahaan atau industri yang diyakini memperoleh keuntungan dari publik atau memperoleh laba sangat tinggi. Laba sangat tinggi mengakibatkan perusahaan ditekan agar menurunkan harga jual atau pemerintah meregulasi harga. Manajer memiliki insentif dalam pemilihan metode akuntansi dan penggunaan diskresi untuk menurunkan laba dan risiko politik. Han \& Wong (1998) mengindikasikan bahwa perusahaan minyak menggunakan discretionary accruals untuk menurunkan laba, saat krisis minyak akibat perang teluk tahun 1990. Penelitian lain melaporkan bahwa manajer bank mengelola penyisihan kerugian piutang (collinset al. 1995) dan manajer asuransi mengelola cadangan kerugian klaim (Adiel 1996) untuk menghindari tekanan dari regulator.
Menurut Scott (1997) terdapat beberapa alasan mengapa manajer melakukan manajemen laba, yaitu:

1) Rencana Bonus (Bonus Scheme)

Dalam usaha untuk mencoba menjelaskan dan memprediksi pemilihan manajer-manajer terhadap kebijakankebijakan akuntansi, secara lebih spesifik ini merupakan perluasan hipotesis rencana bonus, yang menyatakan bahwa para manajer perusahaan yang menggunakan rencana bonus akan memaksimalkan pendapatan masa kini atau tahun berjalan mereka.

2) Kontrak Utang Jangka Panjang (debt covenant)

Motivasi ini sejalan dengan hipotesis kontrak utang jangka panjang dalam teori akuntansi positif yaitu semakin dekat suatu perusahaan ke pelanggaran perjanjian utang maka manajer akan cenderung memilih metode akuntansi yang dapat "memindahkan" laba periode mendatang ke periode berjalan sehingga dapat mengurangi kemungkinan perusahaan mengalami pelanggaran kontrak.

3) Motivasi Politik (Political Motivation)

Perusahaan-perusahaan besar dan industri strategis cenderung menurunkan laba untuk mengurangi visibilitasnya, khususnya selama periode kemakmuran tinggi. Tindakan ini dilakukan untuk memperoleh kemudahan dan fasilitas dari pemerintah misalnya subsidi.

4) Motivasi Perpajakan (Taxation Motivation)

Perpajakan merupakan salah satu alasan utama mengapa perusahaan mengurangi laba yang dilaporkan. Dengan mengurangi laba yang dilaporkan maka perusahaan dapat meminimalkan besar pajak yang harus dibayarkan kepada pemerintah.

5) Pergantian Chief Executive Officer (CEO)

CEO yang akan habis masa penugasannya atau pensiun akan melakukan strategi memaksimalkan laba 
untuk meningkatkan bonusnya. Demikian pula dengan CEO yang kinerjanya kurang baik, ia akan cenderung memaksimalkan laba untuk mencegah atau membatalkan pemecatannya.

6) Penawaran Saham Perdana (initial public offering)

Saat perusahaan go public, informasi keuangan yang ada dalam prospektus merupakan sumber informasi yang penting. Informasi ini dapat dipakai sebagai sinyal kepada calon investor tentang nilai perusahaan. Untuk mempengaruhi keputusan calon investor maka manajer berusaha menaikkan laba yang dilaporkan.

\section{Kebaikan Manajemen Laba}

Konsep komunikasi yang terhambat dari Demski dan Sappington (1987a), secara frekuen, maka agen yang memperoleh informasi yang dispesialisasikan sebagai bagian dari keahlian mereka, dan jenis informasi ini kemungkinan besar akan bernilai untuk berkomunikasi kepada principal, yakni membuka komunikasi yang terhambat diantara perusahaan/manajer dengan pemilik perusahaan atau investor. Demski dan Sappington (1987a) menunjukkan kehadiran dari komunikasi yang diblokir yang bisa menurunkan efisiensi dari kontrak agensi, karena agen kemungkinan akan kekurangan perolehan informasi dan berkompensasi dengan bertindak, jika hal ini terjadi, maka principal akan menerima insentif untuk mencoba mengeliminasi atau menurunkan blockade informasi.

Ada beberapa cara untuk mengurangi blockade. Gu dan Li (2007) melaporkan sebuah reaksi peningkatan pasar yang positif terhadap pengungkapan strategi bisnis oleh perusahaan yang berteknologi tinggi ketika pengungkapan didahului oleh isyarat kepercayaan dalam manajemen perusahaan, yaitu pembelian saham.

\section{Kelemahan Manajemen Laba}

Motivasi untuk manajemen laba yang buruk akan muncul ketika manajer berkeinginan untuk meningkatkan capital share yang baru dan ingin memaksimalkan proses dari isu baru. Sejumlah accruals rahasia bisa dipergunakan untuk meningkatkan net income yang dilaporkan dalam jangka pendek, seperti mempercepat pengenalan dari keuntungan, memperpanjang kemanfaatan dari asset capital, menyusutkan cost restorasi dan lingkungan dan sebagainya.

\section{Strategi Earning Management}

Strategi manajemen laba dapat dibedakan menjadi manajemen laba artifisial dan manajemen laba transaksional (Stolowy dan Breton 2000). Perusahaan melakukan manajemen laba artifisial melalui pemanfaatan fleksibilitas prinsip akuntansi dan pelanggaran prinsip akuntansi. Pemanfaatan fleksibilitas prinsip akuntansi meliputi praktik-praktik akuntansi yang konservatif, netral, dan agresif (Dechow dan Skinner 2000). Manajemen laba transaksional merupakan praktik-praktik operasional atau penciptaan transaksi yang mempengaruhi laba dengan keterlibatan pihak eksternal, misalnya transaksi akuisisi, transaksi divestasi, dan transaksi dengan pihak-pihak dalam hubungan istimewa. Jadi, praktik manajemen laba dapat dikategorikan menjadi tiga, meliputi fleksibilitas prinsip akuntansi, pelanggaran prinsip akuntansi dan manajemen laba transaksional.

\section{Fleksibilitas Prinsip Akuntansi.}

Menurut Beneish 1997 dan Dechow et al. 1995 Fleksibilitas ini meliputi (1) estimasi penyisihan piutang menimbulkan beban penyisihan piutang (2) estimasi penyisihan persediaan menimbulkan beban penyisihan persediaan (3) estimasi umur aktiva atau tarif penyusutan menimbulkan beban penyusutan (Neil et al. 1995 dan Michelson et al. 1995), dan (4) estimasi masa manfaat biaya tangguhan menimbulkan beban amortisasi biaya tangguhan (Beneish 1997 dan Moses 
1987). Perusahaan memiliki kebebasan untuk memperoleh keyakinan mengenai kewajaran beban-beban estimasian ini. Fleksibilitas pengestimasian penyisihan piutang dan penyisihan persediaan merupakan modus tertinggi dalam strategi manajemen laba.

\section{Pelanggaran Prinsip Akuntansi.}

Strategi pelanggaran prinsip akuntansi meliputi (1) tidak mencatat persediaan dalam proses untuk meningkatkan harga pokok penjualan, (2) tidak mencatat laba penjualan aktiva tetap (Bartov 1993), (3) tidak mencatat kerugian penurunan nilai non aktiva operasi (copeland 1968, Schiff 1968, dan Kirchheimer 1968), (4) menggunakan nilai neto persediaan, setelah dikurangi penyisihannya, untuk menaikkan harga pokok penjualan, (5) mencatat investasi kepemilikan saham sebesar 20\% (lebih) dengan metode biaya (Barefield dan Comiskey 1972 dan Dascher \& Malcolm 1970), (6) melaporkan goodwill negatif (selisih lebih nilai buku atas biaya perolehan investasi anak perusahaan) dengan masa amortisasi 20 tahun untuk menurunkan beban amortisasi; dalam hal ini goodwill negatif seharusnya mengurangi biaya perolehan aktiva non lancar, (7) mencatat persediaan fiktif (Beneish 1997); dalam hal ini mencatat persediaan sebesar biaya upah , dan (8) membuat laporan menyesatkan tentang kerugian kehilangan persediaan, dengan tidak mengestimasi pendapatan dari klaim asuransi yang mengurangi kerugian. Kesalahan perhitungan harga pokok penjualan, pelaporan goodwill negatif, dan penyesatan pelaporan kerugian kehilangan persediaan merupakan strategi manajemen laba yang berlaku spesifik.

\section{Manajemen Laba Transaksional.}

Strategi ini meliputi (1) kerugian selisih kurs akibat pembelian impor dalam valuta asing (Brayshawand \& Eldin 1989), (2) akuisisi perusahaan lain yang profitable atau divestasi anak perusahaan yang menderita kerugian (Beneish 1999), (3) pencatatan pendapatan dan harga pokok penjualan fiktif dalam pengakuan pendapatan komisi sebagai perantara penjualan, (4) penyesatan pelaporan transaksi antar perusahaan atau antar perusahaan atau antar pihak dalam hubungan istimewa; dalam hal ini, bentuk-bentuk transaksinya antara lain (a) membuat perjanjian pengalihan aktiva di masa depan dan bersifat kontijensi untuk mengakui keuntungan atau kerugian saat menjelang akhir tahun (Govoly \& Ronen 1981), (b) bertransaksi dengan perusahaan non publik yang terindikasi sebagai perusahaan afiliasi dalam pengendalian hoding company (Beneish 1997, Carlson \& Bathala 1997, serta Beattie et al. 1994, (c) bertransaksi penjualan dan pembelian, berutang dan berpiutang, serta menyewa dan menyewakan ruang dengan perusahaan lain yang terindikasi sebagai perusahaan afiliasi dalam pengendalian holding company (mengindikasikan substansi ekonomi riil sebagai satu kesatuan entitas usaha). Praktik pergeseran pendapatan dan beban antar perusahaan publik di Indonesia. Claessens et al. (2000) menyatakan bahwa pengelolaan perusahaan di Indonesia terpengaruh konsentrasi kepemilikan saham keluarga pendiri. Pendapat ini menguatkan dugaan bahwa perusahaan-perusahaan di Indonesia melakukan manajemen laba antar perusahaan dalam satu grup bisnis yang dikendalikan keluarga pendiri.

Menurut Scott (2003: 383) berbagai pola dan strategi yang sering dilakukan manajer dalam manajemen laba adalah :

\section{a. Taking a bath}

Terjadinya taking a bath pada saat reorganisasi termasuk pengangkatan CEO baru. Bila perusahaan harus melaporkan laba yang tinggi, manajer dipaksa untuk melaporkan laba yang tinggi, konsekuensinya manajer akan menghapus aktiva dengan harapan laba yang akan datang dapat meningkat. Bentuk ini mengakui adanya biaya pada periode yang akan datang sebagai kerugian pada periode berjalan, ketika kondisi buruk yang tidak menguntungkan tidak dapat dihindari pada periode tersebut. Untuk itu manajemen harus menghapus beberapa aktiva dan 
membebankan perkiraan biaya yang akan datang pada saat ini serta melakukan clear the desk, sehingga laba yang dilaporkan di periode yang akan datang meningkat.

b. Income Minimization

Bentuk ini mirip dengan "taking a bath" tetapi lebih sedikit ekstrim, yakni dilakukan sebagai alasan politis pada periode laba yang tinggi dengan mempercepat penghapusan aktiva tetap dan aktiva tak berwujud dan mengakui pengeluaran-pengeluaran sebagai biaya. Pada saat profitabilitas perusahaan sangat tinggi dengan maksud agar tidak mendapat perhatian secara politis, kebijakan yang diambil dapat berupa penghapusan atas barang modal dan aktiva tak berwujud, biaya iklan dan pengeluaran untuk penelitian dan pengembangan, hasil akuntansi untuk biaya eksplorasi.

c. Income Maximization

Tindakan ini bertujuan untuk melaporkan net income yang tinggi untuk tujuan bonus yang lebih besar. Perencanaan bonus yang didasarkan pada data akuntansi mendorong manajer untuk memanipulasi data akuntansi tersebut guna menaikkan laba untuk meningkatkan pembayaran bonus tahunan. Jadi tindakan ini dilakukan pada saat laba menurun. Perusahaan yang melakukan pelanggaran perjanjian hutang mungkin akan memaksimalkan pendapatan.

d. Income Smoothing

Bentuk ini mungkin yang paling menarik. Hal ini dilakukan dengan meratakan laba yang dilaporkan untuk tujuan pelaporan eksternal.

\section{Pengukuran Earning Management}

\section{Model Healy}

Healy Model (1985) menguji manajemen laba dengan membandingkan rata-rata total akrual di seluruh variabel pembagian manajemen laba. Studi Healy berbeda dengan kebanyakan studi manajemen laba lainnya karena ia memprediksi bahwa manajemen laba sistematis terjadi dalam setiap periode. Variabel pemisahnya membagi sampel menjadi tiga kelompok, dengan pendapatan diprediksi akan dikelola ke atas di salah satu kelompok dan ke bawah pada dua kelompok lainnya. Kesimpulan kemudian dilakukan melalui perbandingan berpasangan dari total akrual rata-rata pada kelompok di mana pendapatan diprakirakan akan dikelola ke atas dengan rata-rata total akrual untuk masing-masing kelompok di mana pendapatan diprediksi akan dikelola ke bawah. Pendekatan ini setara dengan memperlakukan seperangkat pengamatan dimana pendapatan diperkirakan akan dikelola ke atas sebagai periode estimasi dan himpunan pengamatan dimana pendapatan diperkirakan akan dikelola ke bawah sebagai periode peristiwa. Total akrual rata-rata dari periode estimasi kemudian mewakili ukuran akrual nondiscretionary. Total accruals (ACC,) yang mencakup discretionary (DAt) dan non-discretionary (NDAt) components, dihitung sebagai berikut (Healy, 1985):

$$
\mathrm{ACCt}=\mathrm{NAt}+\mathrm{DAt},
$$

Selanjutnya total accrual diestimasi dengan menghitung selisih antara laba akuntansi yang dilaporkan dikurangi dengan arus kas operasi. Arus kas merupakan modal kerja dari aktivitas operasi dikurangi dengan perubahan-perubahan dalam persediaan dan piutang usaha, di tambah dengan perubahanperubahan pada persediaan dan utang pajak penghasilan. Sehingga formula selengkapnya menjadi sebagai berikut (Healy, 1985):

$$
\begin{aligned}
& A C C t=-D E P t-(X I t \times D 1)+\triangle A R t+ \\
& \Delta I N V t-\triangle \mathrm{APt}-\{(\Delta \mathrm{TPt}+\mathrm{Dt}) \times \mathrm{D} 2\}
\end{aligned}
$$

Keterangan:

DEPt : Depresiasi di tahun $\mathrm{t}$

Xit : Extraordinary Items di tahun $t$

$\triangle A R t$ : Piutang usaha di tahun $\mathrm{t}$ dikurangi piutang usaha di tahun $\mathrm{t}-1$. 
$\Delta \mathrm{INVt}$ : Persediaan di tahun $\mathrm{t}$ dikurangi persediaan di tahun $\mathrm{t}-1$

$\Delta \mathrm{APt} \quad$ : Utang usaha di tahun $\mathrm{t}$ dikurangi utang usaha di tahun t-1

$\Delta \mathrm{TPt} \quad$ : Utang pajak penghasilan ditahun $\mathrm{t}$ dikurangi utang pajak penghasilan di tahun $\mathrm{t}-1$

D1 : 1 jika rencana bonus dihitung dari laba setelah extarordinary items, 0 jika rencana bonus dihitung dari laba sebelum extarordinary items;

D2 : 1 jika rencana bonus dihitung dari laba sesudah pajak penghasilan, 0 jika rencana bonus dihitung dari laba sebelum pajak penghasilan,

\section{Model DeAngelo}

DeAngelo (1986) menguji manajemen laba dengan menghitung perbedaan pertama dalam total akrual, dan dengan mengasumsikan bahwa perbedaan pertama memiliki nilai nol yang diharapkan berdasarkan hipotesis nol yang menyatakan tidak ada manajemen laba. Model ini menggunakan total akrual periode lalu (diskalakan dengan total aset $\mathrm{t}-1$ ) sebagai ukuran akrual nondiskritioner. Dengan demikian, Model DeAngelo untuk akrual nondiskritioner adalah (DeAngelo, 1986):

$$
\text { NDAt }=\text { TAt }-1
$$

Dechow et al. (1995) menjelaskan bahwa Model DeAngelo dapat dipandang sebagai kasus khusus dari Model Healy, di mana periode estimasi akrual nondiskretioner dibatasi pada pengamatan tahun sebelumnya. Gambaran umum Model Healy dan DeAngelo adalah bahwa keduanya menggunakan total akrual dari periode estimasi ke proxy untuk akrual nondiskretionioner yang diharapkan. Jika akrual nondiskretioner konstan dari waktu ke waktu dan akrual diskresioner memiliki rata-rata nol pada periode estimasi, maka Model Healy dan DeAngelo akan mengukur akrual nondiskritioner tanpa kesalahan. Namun, jika akrual nondiskritioner berubah dari satu periode ke periode lainnya, maka kedua model akan cenderung mengukur akrual nondiskritioner dengan kesalahan. Selanjutnya Dechow et al. (1995) menjelaskan bahwa ketika akrual nondiskretioner mengikuti proses yang konstan, maka model Healy lebih sesuai digunakan. Sebaliknya, jika akrual nondiskretioner mengikuti proses yang acak, maka model DeAngelo lebih sesuai.

\section{Model Jones}

Jones (1991) mengusulkan sebuah model yang menyederhanakan anggapan bahwa akrual nondiskretioner bersifat konstan. Modelnya mencoba mengendalikan efek perubahan pada lingkungan ekonomi perusahaan terhadap akrual nondiskritioner. Model Jones untuk akrual nondiskretioner pada tahun yang bersangkutan adalah (Jones, 1991):

$$
\begin{aligned}
& \text { NDAt }=\alpha 1(1 / \text { At }-1)+\alpha 2 \\
& (\Delta \text { REVt })+\alpha 3 \text { (PPEt) }
\end{aligned}
$$

Keterangan:

$\triangle \mathrm{REVt}$ : pendapatan pada tahun $\mathrm{t}$ dikurangi pendapatan pada tahun t-1 didibagi dengan Total aset pada $\mathrm{t}-1$;

PPEt : property, pabrik dan peralatan pada tahun $t$ dibagi dengan total aset pada $\mathrm{t}-1$;

At-1 : total aset pada tahun $\mathrm{t}-1$;

$\alpha 1, \alpha 2, \alpha 3$ :parameter-parameter

spesifik perusahaan.

Estimasi parameter spesifik perusahaan $(\alpha 1$, $\alpha 2, \alpha 3)$ dihasilkan dengan menggunakan model berikut pada periode estimasi (Jones, 1991):

$$
\begin{aligned}
& \text { TAt }=\mathrm{a} 1(1 / \text { At-1 })+\mathrm{a} 2(\Delta \mathrm{REVt})+\mathrm{a} 3 \\
& (\mathrm{PPEt})+v \mathrm{t},
\end{aligned}
$$

\section{Dimana:}

a1, a2, dan a3 menunjukkan estimasi koefisien regresi dari $\alpha 1, \alpha 2$, dan $\alpha 3$. Sedangkan TA 
adalah total akrual dibagi dengan total aset tahun $\mathrm{t}-1$.

Dechow et al. (1995) menjelaskan bahwa hasil perhitungan Model Jones menunjukkan bahwa model tersebut berhasil menjelaskan sekitar seperempat variasi total akrual. Asumsi yang tersirat dalam model Jones adalah bahwa pendapatan bukan diskresioner. Jika pendapatan dikelola melalui pendapatan discretionary, maka Model Jones akan menghapus sebagian dari pendapatan yang dikelola dari proxy akrual diskresioner. Misalnya, pertimbangkan situasi dimana manajemen menggunakan kebijaksanaannya untuk memperoleh pendapatan pada akhir tahun saat uang belum diterima dan sangat dipertanyakan apakah pendapatan tersebut telah diperoleh. Hasil dari pertimbangan manajerial ini akan meningkatkan pendapatan dan jumlah akrual (melalui peningkatan piutang). Model Jones menterjemahkan total akrual yang berhubungan dengan pendapatan dan oleh karena itu akan mengekstrak komponen akrual diskresioner ini, yang menyebabkan estimasi manajemen laba menjadi bias terhadap nol. Jones mengakui keterbatasan model ini di dalam tulisannya (Dechow et al., 1995).

\section{Model Industri}

Dechow dan Sloan (1991) menyusun model pengukuran manajemen laba yang dikenal dengan Model Industry. Serupa dengan Model Jones, Model Industri menyederhanakan anggapan bahwa akrual nondiskretioner konstan sepanjang waktu. Namun, alih-alih mencoba secara langsung memodelkan faktor penentu akrual nondiskritioner, Model Industri mengasumsikan bahwa variasi dalam faktor penentu akrual nondiskresioner adalah umum di seluruh perusahaan di industri yang sama. Model Industri untuk akrual nondiskritioner adalah (Dechow dan Sloan, 1991) :

$$
\text { NDAt }=\gamma 1+\gamma 2 \text { medianI(TAt) }
$$

Dimana:
medianI(TAt) : nilai median dari total akrual yang diukur dengan aset tahun t-1 untuk semua perusahaan non-sampel dalam kode industri yang sama.

Parameter spesifik perusahaan $\gamma 1$ dan $\gamma 2$ diperkirakan menggunakan koefesien regresi pada pengamatan di Periode estimasi.

Kemampuan Model Industri untuk mengurangi kesalahan pengukuran dalam akrual diskresioner bergantung pada dua faktor. Pertama, Model Industri hanya menghilangkan variasi akrual nondiscretionary yang umum terjadi di perusahaan-perusahaan di industri yang sama. Jika perubahan akrual nondiskretioner mencerminkan respons terhadap perubahan dalam keadaan spesifik perusahaan, maka Model Industri tidak akan mengekstrak semua akrual nondiscretionary dari proxy akrual diskresioner. Kedua, Model Industri menghilangkan variasi dalam akrual diskresioner yang berkorelasi di seluruh perusahaan di industri yang sama, yang berpotensi menimbulkan masalah. Tingkat keparahan masalah ini bergantung pada sejauh mana stimulus manajemen laba berkorelasi di antara perusahaan-perusahaan di industri yang sama (Dechow et al., 1995).

\section{Model Modifikasi Jones}

Dechow et al.

mempertimbangkan versi modifikasi Model Jones dalam analisis empiris. Modifikasi ini dirancang untuk menghilangkan kemungkinan dugaan Model Jones untuk mengukur akrual diskresioner dengan kesalahan ketika diskresi manajemen dilakukan terhadap pendapatan. Dalam model yang dimodifikasi, akrual nondiskretioner diperkirakan selama periode peristiwa (yaitu, selama periode di mana manajemen laba dihipotesakan. Penyesuaian yang dilakukan terhadap Model Jones asli adalah bahwa perubahan pendapatan disesuaikan dengan perubahan piutang pada periode kejadian. Model Jones asli secara implisit mengasumsikan bahwa diskresi tidak 
dilakukan terhadap pendapatan baik dalam periode estimasi atau periode peristiwa. Versi Modifikasi Model Jones secara implisit mengasumsikan bahwa semua perubahan dalam penjualan kredit pada periode kejadian berasal dari manajemen laba, hal ini didasarkan pada penalaran bahwa lebih mudah mengelola pendapatan dengan menerapkan diskresi atas pengakuan pendapatan atas penjualan kredit daripada mengelola pendapatan dengan menerapkan diskresi atas pengakuan pendapatan atas penjualan tunai (Dechow et al., 1995). Jika modifikasi ini berhasil, maka perkiraan manajemen laba seharusnya tidak lagi bias terhadap nol dalam sampel dimana manajemen laba telah dilakukan melalui pengelolaan pendapatan.

\section{Model Dechow-Dichev}

Dechow dan Dichev (2002) mengajukan sebuah model yang bisa digunakan untuk mengukur kualitas akrual dalam laba yang tersaji di laporan keuangan. Pengukuran didasari pada sebuah observasi yang menemukan bahwa akrual akan mampu menyesuaikan perubahan arus kas dari waktu ke waktu. Akan tetapi, seringkali akrual didasari pada suatu estimasi akan peristiwa yang akan datang, yang jika estimasi ini salah maka memerlukan penyesuaian di masa yang akan datang. Dengan demikian, kesalahan estimasi menjadi factor pengganggu yang dapat menurunkan kualitas akrual. Model ini memfokuskan diri pada pemanfaatan akrual untuk kepentingan oportunustis manajer yang dapat menyesatkan para pengguna laporan keuangan. Selanjutnya model ini menjelaskan bahwa karakteristik asal dari proses akrual menyarankan bahwa besaran kesalahan estimasi akan secara sistematis berhubungan dengan hal-hal fundamental perusahaan seperti lamanya siklus operasi perusahaan dan variabilitas operasional perusahaan. Selanjutnya model ini membangun rerangka akrual, dimana laba akan sama dengan arus kas ditambah dengan akrual, dengan formula seperti berikut (Dechow and Dichev, 2002):

$$
\mathrm{E}=\mathrm{CF}+\text { Accruals }
$$

Dari perspektif akuntansi, arus kas (CF) di kategori menjadi arus kas tahun lalu (CFt-1), arus kas tahun berjalan $(\mathrm{CFt})$, dan arus kas masa depan $(\mathrm{CFt}+1)$. Sehingga, rumus selengkapnya dari laba (E) adalah sebagai berikut (Dechow and Dichev, 2002):

$$
\begin{aligned}
& \mathrm{Et}=\mathrm{CFt}-1^{\mathrm{t}}+\mathrm{CFt}^{\mathrm{t}}+\mathrm{CFt}+1^{\mathrm{t}}+\varepsilon \mathrm{t}+1^{\mathrm{t}} \\
& -\varepsilon \mathrm{t}^{\mathrm{t}-1}
\end{aligned}
$$

Dari rumus di atas, porsi akrual yang terdapat dalam laba (At) ditentukan dengan formula sebagai berikut (Dechow and Dichev, 2002):

$$
\begin{aligned}
& \mathrm{At}=\mathrm{CFt}-1^{\mathrm{t}}-\left(\mathrm{CFt}^{\mathrm{t}+1}+\mathrm{CFt}^{\mathrm{t}-1}\right)+ \\
& \mathrm{CFt}+1^{\mathrm{t}}+\varepsilon \mathrm{t}+1^{\mathrm{t}}-\varepsilon \mathrm{t}^{\mathrm{t}-1}
\end{aligned}
$$

Kemudian diukur perubahan modal kerja akrual $(\triangle \mathrm{WC})$ dengan formula sebagai berikut (Dechow and Dichev, 2002):

$$
\begin{aligned}
& \Delta \mathrm{WCt}=\mathrm{b} 0+(\mathrm{b} 1 \mathrm{xCFOt}-1)+(\mathrm{b} 2 \mathrm{x} \\
& \mathrm{CFOt})+(\mathrm{b} 3 \mathrm{xCFOt}+1)+\varepsilon \mathrm{t}
\end{aligned}
$$

\section{Model Kothari}

Kothari et al. (2005) berupaya menyempurnakan Model Jones, dengan menambahkan perubahan return on assets (ROA) untuk mengontrol kinerja. Dengan kata lain, model ini hanya menambahkan perubahan ROA dalam penghitungan akrual diskresioner. Model ini berargumen bahwa memasukan unsure ROA dalam penghitungan akrual diskresioner akan dapat meminimalkan kesalahan spesifikasi, sehingga akan mampu mengukur manajemen laba secara lebih akurat

\section{Model Stubben}

Stubben (2010) menjelaskan bahwa model discretionary revenue (pendapatan diskresioner) lebih mampu mengatasi bias dalam pengukuran manajemen laba jika dibandingkan dengan akrual diskresioner. Hal ini karena model akraul diskresioner banyak menerima kritik akibat adanya bias dari gangguan kesalahan dalam melakukan estimasi atas diskresi manajer. Sehingga Stubben (2010) berargumentasi akan perlunya mengatasi bias tersebut dengan cara 
memusatkan perhatian pengukuran manajemen laba pada salah satu factor pembentuk laba. Dia berargumen bahwa pendapatan merupakan komponen terbesar yang menyumbangkan laba perusahaan dan juga sebagai subjek utama diskresi manajer, sehingga dengan memfokuskan pada pendapatan akan diperoleh estimasi diskresi yang lebih akurat untuk mengukur praktik manajemen laba.

Pendapatan diskresioner adalah selisih antara perubahan aktual piutang dan perubahan piutang yang diprediksi berdasarkan model. Piutang yang terlalu rendah tinggi secara tidak normal mengindikasikan adanya praktik manajemen laba dalam perusahaan. Untuk membandingkan model yang ada, Stubben (2010) membandingkan kemampuan model pendapatan diskresioner dan model akrual diskresioner yang umum digunakan (Jones, 1991; Dechow et al., 1995; Dechow and Dichev, 2002; Kothari et al. 2005) untuk mendeteksi kombinasi manajemen pendapatan dan biaya. Temuan menunjukkan bahwa ukuran pendapatan diskresioner sebenarnya menghasilkan perkiraan yang secara substansial tidak terlalu bias dan kesalahan pengukuran relative kecil dibandingkan dengan model akrual. Dengan menggunakan manipulasi simulasi (Kothari et al., 2005), Stubben (2010) menemukan bahwa model pendapatan menghasilkan perkiraan diskresi yang ditentukan dengan baik untuk perusahaan dalam masa pertumbuhan.

Selanjutnya, formula model pendapatan diskresioner ditentukan dengan langkahlangkah sebagai berikut (Subben, 2010):

(1) Pendapatan (R) terdiri dari nondiscretionary revenues $\left(R^{U M}\right)$ dan discretionary revenues $\left(\delta^{R M}\right)$, sehingga formulanya adalah:

$$
R i t=R i t^{U M}+\delta \mathrm{it}^{R M}
$$

(2) Selanjutnya, bagian (disimbolkan dengan c) nondiscretionary revenues tidak tertagih pada akhir tahun, sehingga model ini mengasumsikan bahwa tidak terjadi penagihan kas atas discretionary revenues. Sehingga, piutang usaha $(A R)$ akan setara dengan jumlah nondiscretionary revenues yang tidak tertagih $\left(c \times R^{U M}\right)$ dan discretionary revenues $\left(\delta^{\mathrm{RM}}\right)$. Sehingga formula berikutnya adalah:

$$
A R i t=c x\left(R_{i t}^{U M}+\delta \mathrm{it}^{R M}\right)
$$

(3) Asumsi berikutnya adalah bahwa discretionary revenues meningkatkan piutang usaha dan pendapatan dengan jumlah yang sama. Dengan kata lain, discretionary receivables sama dengan discretionary revenues. Karena nondiscretionary revenues tidak dapat diobservasi, model ini mengatur ulang persyaratan-persyaratannya dan mengungkapkan ending receivables sebagai pendapatan yang dilaporkan. Kemudian digunakan selisih pertama untuk mengungkapkan the receivables accrual. Sebagai berikut:

$$
\text { ARit }=c \times \text { Rit }+(1-c) x \delta i t^{R M}
$$

(4) Estimasi discretionary revenues perusahaan sebagai ukuran manajemen laba ditentukan dari nilai residual persamaan berikut :

$$
\text { ARit }=\alpha+\beta \text { Rit }+\varepsilon \text { it }
$$

\section{KESIMPULAN}

Pemahaman atas earnings management dapat diklasifikasikan menjadi dua. Pertama, melihatnya sebagai perilaku oportunis manajer untuk memaksimalkan utilitasnya dalam menghadapi kontrak kompensasi, kontrak utang, dan political cost. Kedua, dengan memandang manajemen laba dari perspektif efficient contracting (Efficient Earning Management), dimana manajemen laba memberi manajer suatu fleksibilitas untuk melindungi diri mereka dan perusahaan dalam mengantisipasi kejadian-kejadian yang tak terduga untuk keuntungan pihak-pihak yang terlibat dalam kontrak. 
Earning management dapat terjadi karena tiga faktor yaitu dengan cara: pemanfaatan transaksi akrual, perubahan metode akuntansi dan penerapan suatu kebijakan. Earning Management merupakan tindakan manajer untuk meningkatkan (mengurangi) laba yang dilaporkan saat ini atas suatu unit dimana manajer bertanggung jawab, tanpa mengakibatkan peningkatan (penurunan) profitabilitas ekonomis jangka panjang unit tersebut.

Earning management terjadi ketika para manajer menggunakan keputusannya dalam melakukan penyusunan transaksi untuk mengubah laporan keuangan baik untuk menimbulkan gambaran yang salah bagi stakeholders tentang kinerja ekonomis perusahaan, ataupun untuk mempengaruhi hasil kontraktual yang bergantung pada angka-angka akuntansi yang dilaporkan.

Adanya earnings management pada suatu perusahaan tidak terlepas dari berbagai macam atau faktor motivasi yang mendasarinya, adapun beberapa motivasi yang terkait dengan pelaksanaan earnings management yakni, motivasi bonus, motivasi politik, motivasi perpajakan, motivasi pergantian CEO, motivasi IPO.

Model - model yang digunakan dalam pengukuran earnings management antara lain: Model Healy, Model DeAngelo, Model Jones, Model Industri, Model Modifikasi Jones, Model Dechow-Dichev, Model Kothari dan Model Stubben.

\section{REFERENSI}

Collins, D., Pincus, M., and Xie, H. (1999). Equity Valuation and Negative Earnings: The Role of Book Value of Equity. The Accounting Review, 74(1), 29-61.

Davidson, W. N., Jiraporn, P., Kim, Y. S. \& Nemec, C. (2004). Earnings Management Following DualityCreating Successions: Ethnostatistics, Impression Management, and Agency Theory. Academy of Management Journal, 47 (2), 267-275.
Dechow, P. \& Dichev, I. (2002). The Quality of Accruals and Earnings: The Role of Accrual Estimation Error. The Accounting Review, 77, 35-59.

Dechow, P., Hutton, A., Kim, J. \& Sloan, R. (2011). Detecting Earnings Management: A New Approach. Working Paper, University Arizona, USA.

Dechow, P., \& Sloan, R. (1991). Executive Incentives and The Horizon Problem: An Empirical Investigation. Journal of Accounting and Economics, 14, 51-89.

Dechow, P., Sloan, R. \& Sweeney, A. (1995). Detecting Earnings Management. The Accounting Review, 70, 193-225.

Demski, J. (1998). Performance Measure Manipulation, Contemporary Accounting Research, 15, 261-285.

Demski,J., dan D.E.M. Sappington, "Fully Revealing Income Measurement," The Accounting Review (April 1990),pp.363-383

Ecker, F., Francis, J., Olsson, P., \& Schipper, K. (2011). Peer Firm Selection for Discretionary Accrual Models. Working Paper, Duke University.

Erickson, M., \& Wang, S. W. (1999). Earnings Management by Acquiring Firms in Stock for Stock Mergers. Journal of Accounting and Economics, 27 (2), 149-176.

Guay, W. R., Kothari, S.P., \& Watts, R. (1996). A Market Based Evaluation of Discretionary Accruals Models. Journal of Accounting Research, 34, 83-105.

Healy, P. (1985). The Effect of Bonus Schemes on Accounting Decisions. Journal of Accounting andEconomics, 7, 85-107.

Healy, P. M. \& Palepu, K.G (1993). The Effect of Firms' Financial Disclosure Policies on Stock Prices', Accounting Horizons, 7, 1-11.

Healy, P. M. \& Wahlen, J. M. (1999). A Review of The Earnings Management Literature And Its Implications For 
Standard Setting. Accounting Suwardjono. 2005. Seri Teori Akuntansi : Horizons, 13 (4), 365-383. pelaporan akuntansi keuangan. Ed. 3 Jones, Jennifers (1991), "Earnings Management During Import Relief Investigation". Journal of Accounting Research 29 Autumn. p. 193-228.

Scott, William R. (1997). " Financial Accounting Theory". New Jersey Prentice-Hall International, A Simon Schuster Company. Upper Suddle River. p 38-39

Scott, W.R. 2012. Financial Accounting

Theory. Toronto, Ontario: Pearson

Education, inc. Canada.

Sugiri, Slamet (1998). "Earning Management : Teori, Model, dan Bukti Empiris". Telaah, hal 1-18

Myers, J. N., Myers, L. A., \& Skinner, D. J. (2007). Earnings Momentum and Earnings Management. Journal of Accounting, Auditing \& Finance, 22 (2), 249-284.

Watts, R., \& Zimmerman, J. (1986). Positive Accounting Theory. Prentice-Hall, Englewood Cliffs, NJ, USA. 